\title{
Kajian Tentang Smart City: Paradigma, Kesempatan, Permasalahan Yang Ada Di Kabupaten Purworejo
}

\author{
Wahju Tjahjo Saputro ${ }^{1 *}$, Bambang Priyo Darminto ${ }^{2}$ \\ ${ }^{1}$ Teknologi Informasi, Universitas Muhammadiyah Purworejo, Purworejo 54111, Indonesia \\ ${ }^{2}$ Pendidikan Matematika, Universitas Muhammadiyah Purworejo, Purworejo 54111, Indonesia
}

\begin{abstract}
Abstrak
Sepuluh tahun terakhir ini, baik akademisi maupun para peneliti sedang tertarik melakukan penelitian tentang smart city beserta aspek-aspeknya. Hasil penelitian mereka tertuju pada satu poin bahwa lompatan teknologi informasi yang signifikan mempengaruhi arsitektur, infrastruktur dan pola masyarakat terhadap kebutuhan informasi yang cepat dan dapat diakses di manapun. Paradigma ini melahirkan konsep smart city yaitu sebuah kota yang terencana dengan baik, layanan masyarakat yang hemat biaya dan tata kelola yang baik untuk kesejahteraan masyarakat.

Kajian ini bertujuan memberikan gambaran secara komprehensif tentang konsep smart city yang terkait pada kendala geografis, lingkungan, ekonomi, dan sosial. Kajian ini memberikan gambaran tentang karakteristik enam dimensi smart city dengan aspek smart living, smart mobility, smart people, smart economy, smart environment, smart goverment. Kehidupan kota modern merupakan bagian dari masyarakat dalam memenuhi kebutuhan hidup. Masyarakat terbiasa mobilitas tinggi antarkota karena pekerjaan, hiburan, pendidikan, fenomena urbanisasi dan menipisnya sumberdaya tertentu.

Akibat perkembangan teknologi informasi dan komunikasi saat ini, konsep smart city memberikan kesempatan kepada masyarakat untuk menikmati layanan, membuat keputusan, menemukan sesuatu yang baru dan banyak hal yang dialami untuk meningkatkan kualitas hidup di era sekarang.
\end{abstract}

Kata Kunci : Paradigma, Smart city, Teknologi informasi

\begin{abstract}
In the last ten years, both academics and researchers have been interested in conducting research on smart city and its aspects. The results of their research are focused on one point that the leap in information technology that significantly influences the architecture, infrastructure and community patterns of information needs is fast and can be accessed anywhere. This paradigm gave birth to the concept of smart city, which is a well planned city, cost-effective community services and good governance for the welfare of society.
\end{abstract}

This study aims to provide a comprehensive picture of the smart city concept that depends on geographical, environmental, economic and social constraints. This paradigm provides an overview of the six dimensions of smart city characteristics with aspects of smart living, smart mobility, smart people, smart economy, smart environment, smart government. Modern city life is part of the community in fulfilling their daily needs. People are accustomed to high mobility between cities because of work, entertainment, education, the phenomenon of urbanization and depletion of certain resources.

Thanks to the development of information and communication technology, the concept of smart city now provides an opportunity for people to enjoy services, make decisions, find something new and experience many things to improve the quality of life in the smart city era.

Keywords : Paradigm, Smart city, Information tehcnology 


\section{PENDAHULUAN}

\subsection{Latar Belakang}

Secara garis besar, smart city adalah sebuah konsep kota yang membantu masyarakat yang berada di dalamnya dengan mengelola sumber daya yang ada dengan efisien dan memberikan informasi yang tepat kepada masyarakat di dalamnya untuk melakukan kegiatan atau mengantisipasi kejadian yang tidak terduga (Supangat, 2015). Pertumbuhan ekonomi yang meningkat, penataan lingkungan sehat, pembangunan yang pesat dan kelas social yang tinggi memicu proses urbanisasi (A. Arroub, dkk., 2016). Sehingga keadaan urbanisasi mampu menggeser kehidupan konvensional kearah modern yang menuntut hidup lebih efisien. Perkembangan teknologi informasi turut memicu masyarakat berpola hidup modern.

Smart city merupakan sistem paradigma baru di era disruptif atau industri 4.0 dimana perkembangan perangkat teknologi informasi sangat cepat. Di Indonesia konsep smart city diinisiasi oleh pakar dari ITB, Suhono S. Supangat. Smart city adalah kota yang paling cepat dan akurat memberikan solusi kepada masyarakat. Konsep smart city terdiri dari 6 (enam) komponen pendukung yaitu: smart economy, smart people, smart governance, smart mobility, smart environment dan smart living (Supangat, 2015).

Menurut Pusat Studi Perencanaan Pembangunan Regional (PSPPR) UGM dalam penelitiannya menyampaikan ada 6 (enam) bidang sebuah kota layak disebut smart city. Keenam bidang tersebut yaitu smart economy, smart mobility, smart environment, smart people, smart living, smart governance. Masing-masing dimensi smart tersebut masih dirinci lagi. Sedangkan Indonesia yang berada pada ring of fire, menambah atribut smart disaster menjadi satu dimensi wajib dan layak disematkan (Jawa Pos, 2018). Dengan demikian konsep smart city khusus di Indonesia dapat dikatakan ada 7 (tujuh) smart supaya masyarakat merasa nyaman untuk tinggal, ditunjukkan Gambar 1.

\subsection{Konsep Smart City}

Beberapa kota besar di Indonesia yang sudah menuju smart city dan masih terus ditingkatkan yaitu Jogjakarta, Bandung, Jakarta, Makasar, Semarang, Kutai Kartanegara, Samarinda (Jawa Pos, 2018). Sedangkan beberapa kota besar di luar negeri yang telah menerapkan konsep smart city yaitu Kopenhagen di Denmark, Seoul di
Korea Selatan, Shanghai Tiongkok, Ahmedebad India (https://kominfo.go.id/content/detail, 2019). Di mana setiap kota di negara tersebut memiliki keunggulan tersendiri di bidang smart. Artinya tidak harus keenam elemen terpenuhi untuk menuju smart city.

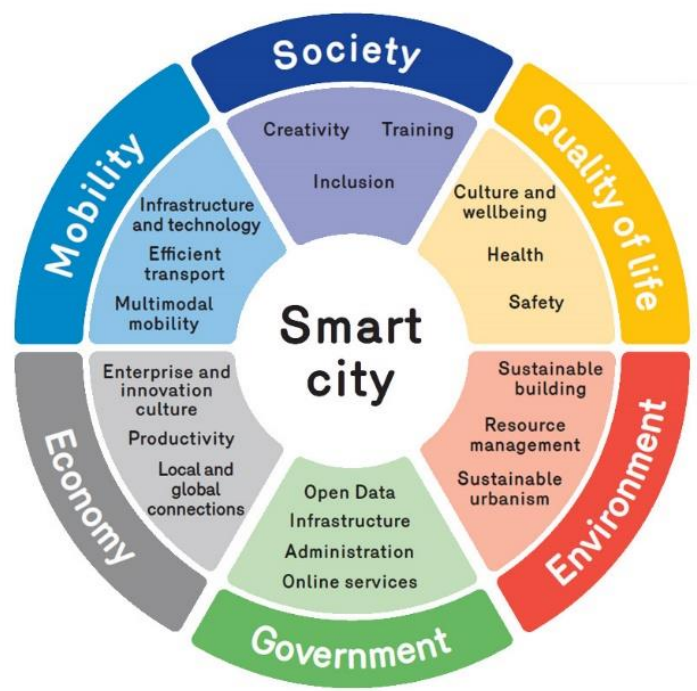

Gambar 1. Enam Komponen Pendukung Smart City (https://smartcity.brussels/the-projectdefinition, Mei 2019)

Kota Kopenhagen di Denmark, merupakan smart city berfokus pada meningkatkan bidang lingkungan. Kota Seoul di Korea Selatan memfokuskan diri pada pelayana publik bidang teknologi informasi karena memiliki jaringan internet tercepat di dunia. Shanghai di Tiongkok smart city fokus pada aspek bidang bisnis. Sedangkan kota Ahmedebad di India unggul sebagai smart city bidang aspek environment (lingkungan). (https://kominfo.go.id/content/detail, 2019).

Gerakan menuju 100 smart city merupakan program bersama yaitu Kominfo, Kemendagri, Kementrian PUPR, Bappenas dan Kantor Staf Kepresidenan. Gerakan menuju 100 smart city bertujuan mengarahkan kabupaten dan kota di Indonesia dalam menyusun masterplan smart city dalam mengoptimalkan manfaat teknologi informasi untuk akselerasi pelayanan masyarakat dan meningkatkan potensi masing-masing daerah.

Sebuah kota atau kabupaten dapat disebut smart city bila memiliki infrastruktur dasar teknologi informasi, didukung suprastruktur yaitu kebijakan pemerintah daerah, memiliki sistem transportasi yang efisien dan terintegrasi. Sehingga dampak bagi masyarakat yaitu meningkatkan mobilitas, mendukung kualitas hidup, rumah bangunan yang 
hemat energi, ramah lingkungan dan menggunakan energi terbarukan.

Konsep smart city juga menyentuh aspek lingkungan. Seperti menerapkan lingkungan yang lebih lestari, pengaturan limbah indsutri dan limbah masyarakat yang lebih maju, pengelolaan air yang lebih baik. Aspek pariwisata smart city menyentuh bagaimana meningkatkan wisatawan, menarik investor, menarik penghuni baru dengan berbagai profesi akademisi, profesional, usahawan (urban). Indikatornya adalah kota smart city memiliki daya tarik yang kuat pada berbagai aspek atau beberapa aspek tertentu.

Konsep smart city mengakibatkan layanan kepada masayarakat lebih efisien, kinerja pemerintahan juga lebih efektif. Teknologi informasi bukan sekedar berada di kota atau milik masyarakat perkotaan. Namun teknologi informasi diharapkan mampu menyentuh masyarakat yang tinggal di pedesaan sehingga aspek smart people dapat terpenuhi. Hal ini ditunjukkan dengan indikator akses dan jaringan internet yang mudah diperoleh masyarakat. Dengan demikian produktivitas pedesaan dan daya saing ekonomi pedesaan meningkat. Maka dampak smart living dan smart economy bagi masyarakat desa akan dirasakan.

\subsection{Paradigma Smart City}

Di dalam konsep smart city akan dijumpai berbagai aspek. Diantaranya aspek kepedulian, aspek fleksibilitas, aspek transformasi, aspek sinergi, aspek individual, aspek menentukan diri sendiri dan aspek strategi untuk mencapai sesuatu yang smart ketika hidup di lingkungan smart city. Ketika sebuah kota dimana didalamnya terdapat kelompok sistem, maka beberapa penelitian sebelumnya mengidentifikasi sebagai ciri khas dari smart city (A. Arroub, dkk., 2016). Sebuah proyek Uni Eropa menjelaskan paradigma smart city mengacu pada struktur hirarki yang ditunjukkan pada Gambar 2 (Giffinger R., dkk, 2007).

Pada Gambar 2 tersebut dimana smart economy digambarkan dengan inovasi, kewirausahaan, sesuatu yang produktif, ekonomi kreatif, merk dagang dipatenkan dan integrasi semua jenis usaha.

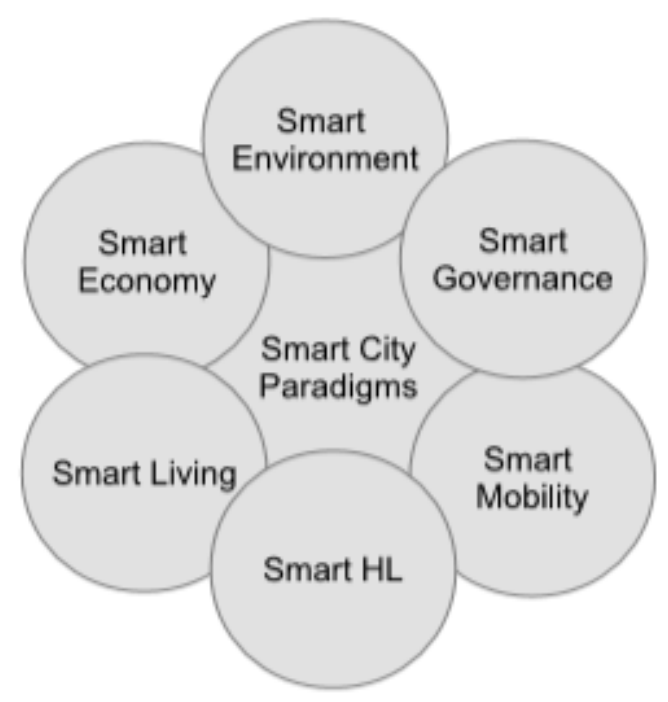

Gambar 2. Paradigma Smart city (Giffinger R., dkk, 2007).

Untuk smart people pada penelitian tersebut ditemukan istilah smart HL (human living) menggambarkan tingkat pendidikan, kualitas hidup dan interaksi sosial yang baik. Smart government mencakup semua aspek politik, administrasi dan layanan publik. Smart mobility meliputi aksesbilitas transportasi yang lengkap, ketersediaan ICTS, dan sistem baru yang berkelanjutan. Smart environment didasarkan pada kondisi alam wilayah setempat dan lingkungan yang nyaman. Smart living berkaitan dengan semua hal yang mencakup kualitas hidup (A. Arroub, dkk., 2016).

Menurut para peneliti (Torres L., dkk., 2005), (Hollands R. G., 2008), (Arifin A., 2014), (Davies A.R. and Mullin S.J., 2008) bahwa karakteristik umum dari smart economy yaitu Inovatif; ide yang meningkatkan produktivitas dan mengurangi biaya. Digital; meluasnya penggunaan TIK dalam perekonomian. Kompetitif; bersikap terbuka, menggunakan pengetahuan dan inovasi untuk mendapatkan kualitas yang baik dari keuntungan yang lebih tinggi, sumber daya produktif dan biaya yang efisien. Hijau; fokus pada fundamental yang berkelanjutan, gunakan sumber daya energi alami dan memulihkan area menjadi bersih. Tanggungjawab sosial; berusaha untuk mempromosikan kesejahteraan individu.

Smart environment meliputi meningkatkan keberlanjutan, sebuah kota dikelola dengan dukungan suprastruktur dan infrastruktur. Lingkungan yaitu: saluran air yang baik, saluran irigasi yang layak, tata ruang hijau yang nyaman. Komponen tersebut harus didasarkan pada 
penggunaan sumberdaya energi yang ramah lingkungan (Campbell T., 2009).

Smart governance: serangkain proyek smart city melibatkan partisipasi berbagai pemangku kepentingan. Inisiatif mengelola proyek lebih baik, sebuah kota harus meningkatkan kualitas tatakelolanya. Berkat perkembangan teknologi informasi sebuah kota berupaya menunjukkan sebuah kota dengan pemerintahan dengan tatakelola yang cerdas berbasis teknologi informasi. Hal ini mewakili aspek teknologi informasi, aspek masyarakat, aspek kebijakan, aspek layanan, aspek sumberdaya, aspek norma sosial yang saling berinteraksi guna mendukung kegiatan pemerintah daerah yang bersih dan cerdas (H. Chourabi dkk., 2012). Pada sebuah studi (Scholl H.J. dkk., 2009), keberhasilan proyek e-governance tergantung pada hubungan antar pemangku kepentingan di tingkat daerah yang mengacu pada empat masalah utama: kemampuan bekerja sama antar pemangku kepentingan, dukungan pemimpin daerah, struktur aliansi dan bekerja di bawah yurisdiksi yang berbeda.

Smart Living: ada korelasi informasi dalam penyajiannya, masyarakat mampu mengembangkan cara hidup yang cerdas melalui teknologi. Semua tugas terhubung ke perangkat teknologi sehingga lebih mudah diselesaikan, lebih aman dan lebih murah (Clay G. Nesler dkk.,, 2010).

Smart mobility, semakin beragam moda transportasi saat ini. Dimana beberapa tahun silam moda transportasi dikelola, melakukan transaksi, pelayanan secara konvensional. Seiring perkembangan perangkat teknologi informasi maka moda transportasi beralih memanfaatkan kecanggihan teknologi informasi modern. Dimana transaksi dapat dilakukan secara real time melalui perangkat mobile. Tatakelola dan kualitas pelayanan mengalami peningkatan. Dampaknya masyarakat merasa nyaman, efisien dan praktis dalam memilih moda transportasi untuk mendukung aktivitasnya.

Smart HL: Kota tidak dapat mencapai kecerdasan tanpa kreativitas, pendidikan yang berkualitas, pengetahuan yang baik, dan pembelajaran yang efektif. Jadi, ketika berbicara tentang smart city, dimensi masyarakat sebagai modal SDM sangat penting. Jika hal tersebut tidak tercapai akibatnya keempat komponen yaitu smart living, smart economy, smart governance, smart mobility tidak dapat berjalan dengan baik.

\subsection{Smart City Di Indonesia}

Rudiantara dalam http://kominfo.go.id/content/detail, (2019) menyampaikan tahap awal pembangunan smart city difokuskan pada 24 kota kabupaten. Dimana dalam menentukan pembangunan smart city, salah satu tolok ukurnya adalah tersedia ruang fiskal. Di Indonesia terdapat 514 kabupaten kota dimana tidak semua memiliki ruang fiskal yang memadai. Ketersediaan ruang fiskal menjadi syarat mutlak untuk membangun smart city. Sebab jika 80\% dari total APBD dialokasikan belanja rutin maka pemerintah daerah kesulitan mengembangkan smart city. Karena $20 \%$ dari APBD hanya dibelanjakan barang guna menunjang smart city. 24 kota kabupaten yang telah menerima penghargaan gerakan menuju 100 smart city tahun 2017 tampak pada Tabel 1.

Tabel 1. 24 Kota Kabupaten Penerima Penghargaan Smart City 2017

\begin{tabular}{|c|l|}
\hline No & \multicolumn{1}{|c|}{ Kota / Kabupaten } \\
\hline 1 & Kab. Banyuwangi \\
\hline 2 & Kota Tomohon \\
\hline 3 & Kab. Lombok Timur \\
\hline 4 & Kota Sukabumi \\
\hline 5 & Kab. Bandung \\
\hline 6 & Kota Samarinda \\
\hline 7 & Kota Bandung \\
\hline 8 & Kota Semarang \\
\hline 9 & Kota Tangerang \\
\hline 10 & Kab. Sleman \\
\hline 11 & Kota Bekasi \\
\hline 12 & Kota Bogor \\
\hline 13 & Kota Cirebon \\
\hline 14 & Kota Pelalawan \\
\hline 15 & Kab. Banyuasin \\
\hline 16 & Kab. Bojonegoro \\
\hline 17 & Kab. Gresik \\
\hline 18 & Kab. Sidoarjo \\
\hline 19 & Kota Makasar \\
\hline 20 & Kota Tagnerang Selatan \\
\hline 21 & Kota Kabupaten Mimika \\
\hline 22 & Kab. Kutai Kartanegara \\
\hline 23 & Kota Jambi \\
\hline 24 & Kabupaten Siak \\
\hline
\end{tabular}

Sumber:

http://www.neraca.co.id/article/93533/langkah-menuju100-smart-city

Smart city dapat terwujud bila memiliki modal utama berupa ruang fiskal yang cukup, sumberdaya manusia yang mampu berperan aktif. Tujuan dari smart city adalah kemudahan akses 
dan layanan masyarakat. Kedua kunci tersebut harus dikelola dengan baik. Khususnya smart mobility yang terkait erat dengan smart economy. Dimana daya beli masyarakat yang kuat dapat meningkatkan pendapatan sektor ekonomi daerah berdampak pada mobilitas masyarakat semakin tinggi. Saat ini paradigma smart city masih berkaitan dengan teknologi informasi. Sesungguhnya smart city memiliki cakupan yang luas dimana keenam aspek smart saling berkaitan agar smart city dapat terwujud dan dirasakan manfaatnya oleh masyarakat.

\subsection{Smart City Jawa Tengah}

Menurut Badan Pusat Statistik, pada tahun 2014 populasi penduduk di Indonesia yang tinggal di wilayah perkotaan telah mencapai diatas $50 \%$ dari total populasi penduduk di Indonesia. Jumlah ini cenderung meningkat dan diperkirakan penduduk yang tinggal di wilayah perkotaan akan mencapai $65 \%$ pada tahun 2035. Khusus propinsi Jawa Tengah peningkatan urbanisasi ditunjukkan pada Tabel 2 dalam prosentase (Badan Pusat Statistik, 2017). Perlahan namun pasti kota atau kabupaten di wilayah Jawa Tengah akan mengalami urbanisasi akibat paradigma smart city.

Pertumbuhan ini dipicu oleh kelahiran dan urbanisasi karena daya tarik wilayah perkotaan yang dilengkapi infrastruktur teknologi informasi, berbagai kemudahan layanan, fasilitas yang menopang gaya hidup modern. Urbanisasi yang relatif cepat menimbulkan berbagai masalah khas perkotaan. Seperti kemacetan, banjir, kecelakaan, sampah, lingkungan dan kriminal.

Tabel 2. Perkiraan Populasi Penduduk di Propinsi Jawa Tengah

\begin{tabular}{|c|c|c|c|c|c|}
\hline $\mathbf{2 0 1 0}$ & $\mathbf{2 0 1 5}$ & $\mathbf{2 0 2 0}$ & $\mathbf{2 0 2 5}$ & $\mathbf{2 0 3 0}$ & $\mathbf{2 0 3 5}$ \\
\hline 45.7 & 48.4 & 51.3 & 54.3 & 57.5 & 60.8 \\
\hline
\end{tabular}

Dalam Supangat, (2015) Peningkatan urbanisasi wilayah kota tidak didukung dengan infrastruktur dan peningkatan kapasitas pemerintah dalam menyediakan layanan yang layak. Seperti sumber energi terbarukan, pendidikan, perawatan kesehatan, transportasi umum, keamanan yang layak. Keterbatasan dana pemerintah daerah dimana ruang fiskal menjadi kendala dan alasan.

Modal utama smart city adalah SDM dan partisipasi masyarakat. Dengan modal smart people yang tersedia, maka cukup mudah pemerintah daerah memfasilitasi masyarakat. Namun untuk membangun masyarakat daerah menuju smart people cukup sulit dan beragam permasalahannya.

\subsection{Geografis Kab. Purworejo}

Kabupaten Purworejo terbagi dalam 16 kecamatan dan 494 desa/kelurahan. Wilayah Kabupaten Purworejo pada tahun 2016 mempunyai luas 103.481 ha atau sekitar 3.18\% dari luas Propinsi Jawa Tengah. (Badan Pusat Statistik Kab. Purworejo, 2017)

Kabupaten Purworejo yang memiliki kuntur geografis perbukitan disisi utara dan kontur landai disisi selatan memiliki pola kehidupan masyarakat yang berbeda. Wilayah Kab. Purworejo sisi utara memiliki wilayah dataran lebih tinggi, rawan kebencanaan, infrastruktur yang kurang memadai, fasilitas teknologi informasi yang kurang dirasakan masayarakat. Memicu pola masyarakat untuk bercocok tanam pohon keras, pohon manggis, pohon durian, pohon rambutan dan jenis pohon lain yang produktif. Kualitas bangunan yang dimiliki pun tidak sekokoh wilayah selatan, hal ini sebagai antisipasi bencana alam yang timbul tiba-tiba. Wilayah Kab. Purworejo yang perbukitan mengakibatkan akses informasi dan internet belum terasa manfaatnya bagi masyarakat.

Wilayah Kab. Purworejo sisi selatan dengan kuntur tanah yang landai dan datar, pola masyarakat yang bercocok tanam berupa padi, palawija dan tanaman pertanian lainnya. Akses teknologi informasi yang mudah dimanfaatkan oleh masyarakat dapat diberdayakan dengan potensi daerah lokal dengan cara membangun aplikasiaplikasi sesuai kebutuhan. Menggiatkan pasar digital guna menguatkan smart economy sehingga smart mobility dapat tercapai.

Bandara NYIA (New Yogyakarta International Airport) memberikan dampak positif bagi masyarakat dan Pemerintah Kab. Purworejo. Maka Kab. Purworejo diminta menangkap peluang potensi yang dapat diangkat dalam menumbuhkan perekonomian masyakarat Purworejo (http://semarang.bisnis.com, 2019) menuju smart city dari aspek smart mobility dan smart economy. Keberadaan NYIA juga menopang Candi Borobudur sebagai destinasi obyek wisata vital, dimana jalur menuju obyek tersebut melewati Kab. Purworejo (http://suaramerdeka.com, 2019). Hal ini menimbulkan dampak smart mobility, smart economy, smart living di Kab. Purworejo akan meningkat. 


\section{METODE}

Penelitian ini merupakan kajian atau lietaratur tentang smart city dengan lokasi Kab. Purworejo. Di mana pimpinan pemerintah daerah Kab. Purworejo mencanangkan tahun 2019 Kab. Purwoerejo menuju smart city. Metode yang digunakan dalam penelitian ini mengumpulkan berbagai bahan literatur yang terkait dengan smart city dan cankupannya. Data yang diperoleh berdasarkan hasil literatur dan pengkajian. Dari data tersebut dikumpulkan, kemudian dianalisa mulai potensi yang dimiliki, hambatan yang dihadapi dan kesempatan yang ada. Langkah penelitian ini ditunjukkan pada Gambar 3.

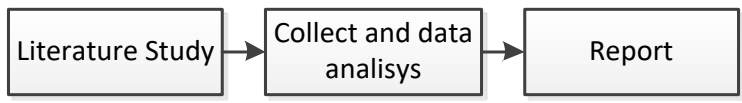

Gambar 3. Metode Penelitian

\section{HASIL DAN PEMBAHASAN}

Sebuah kota modern saat ini mengharuskan perlunya kemampuan baru karena pemerintah semakin mengadopsi teknologi baru. Area konsep kota yang lebih aman diharapkan mendapatkan daya tarik yang signifikan. Faktor penting dalam menciptakan kota yang aman adalah platform terintegrasi dimana banyak pemangku kepentingan terkait dan sistem keamanan yang berbeda mampu bekerja sama memberikan pengawasan yang baik terhadap kota (Santosa B. dan Umam A., 2018). Berikut ditunjukkan pada Tabel 3 komponen smart city dimana komponen tersebut merupakan masalah yang harus diselesaikan oleh setiap kota yang menuju smart city (Sandhi H. dkk., 2017).

Tabel 3. Komponen Smart City (Sandhi H. dkk., 2017).

\begin{tabular}{|c|l|}
\hline No & \multicolumn{1}{|c|}{ Permasalahan Kota } \\
\hline 1 & ICT \\
\hline 2 & Infrastruktur \\
\hline 3 & Pendidikan \\
\hline 4 & Industri \\
\hline 5 & Transportasi \\
\hline 6 & Ekonomi \\
\hline 7 & Governance \\
\hline 8 & SDM \\
\hline 9 & Kesehatan \\
\hline 10 & Open space \\
\hline 11 & Recources \\
\hline 12 & Wisatawan \\
\hline 13 & Lingkungan \\
\hline
\end{tabular}

\begin{tabular}{|l|l|}
\hline 14 & Government \\
\hline 15 & Kenyamanan dan Keamanan \\
\hline 16 & Energi terbarukan \\
\hline
\end{tabular}

Pointer kesiapan yang dilakukan oleh Kab. Purworejo mencakup 8 (delapan) elemen, ditunjukkan pada Gambar 4 seperti disampaikan oleh Sri Palupi Kabid Statistik dan TI Diskominfo Kab. Purworejo dalam Forum Komunikasi dan OPD Maret 2019. Aspek SDM, Kab. Purworejo memiliki pranata komputer 71 orang. Jumlah ini cukup untuk membangun smart city dengan berbagai aplikasi yang diberlukan. Anggaran Kab. Purworejo masih berfokus pada sektor pengentasan kemiskinan, pembangunan, dan mengatasi bencana alam. Suprastruktur sudah cukup untuk mendukung membangun smart city. Analisis visi Kab. Purworejo telah terarah menuju smart city yang didukung analisis GAP.

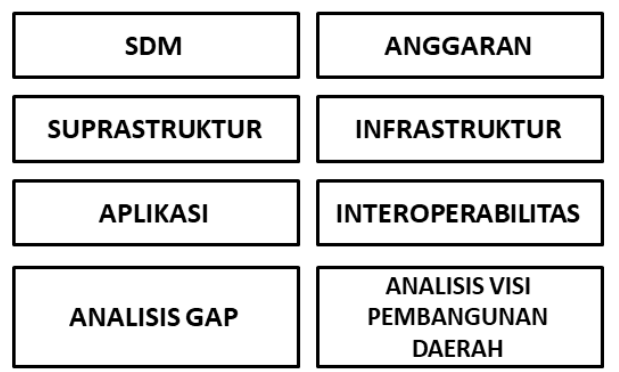

Gambar 4. Pointer Kesiapan (Forum Komunikasi, 2019)

SDM yang dimiliki Kab. Purworejo ditunjukkan pada Gambar 5 (BPS, 2017). Usia produktif berada di kelompok 20 - 54 tahun. Artinya Kab. Purworejo dalam membangun smart city sudah pantas karena memiliki masyarakat potensi usia produktif yang cukup. Tentu harus ditunjang dengan tingkat pendidikan yang baik, agar memiliki smart people.

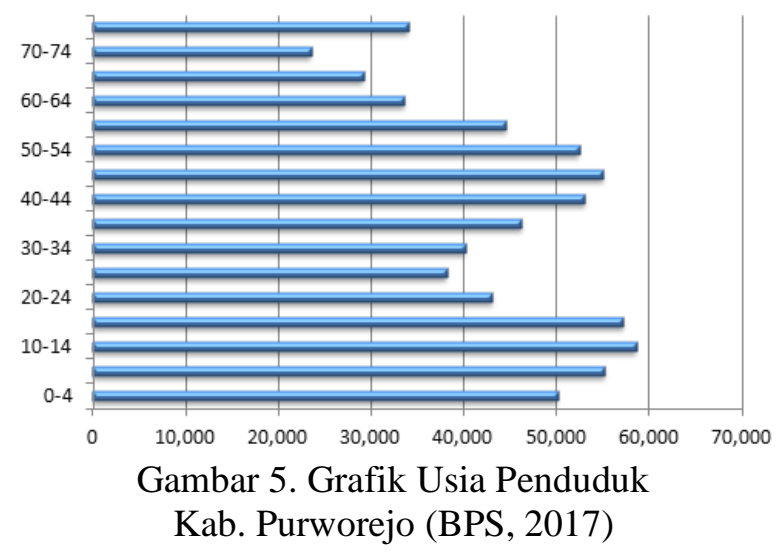

Gambar 6 data grafik sektor pertanian yang mampu mendukung smart economy mencapai 
$40 \%$, terdiri dari pertanian, kehutanan, perburuan dan perikanan. Urutan kedua di dominasi pedagang besar, eceran, rumah makan dan perhotelan mencapai $21 \%$. Sektor dibawah $20 \%$ yaitu industri pengolahan $17 \%$, jasa kemasyarakatan $12 \%$ dan sektor lain 10\%. Dengan demikian pemerintah Kab. Purworejo potensial untuk menggarap aplikasi, infrastruktur yang belum dimiliki guna mendukung smart economy, smart mobile, dan smart living.

Kab. Purworejo menuju smart city telah didukung oleh suprastruktur yang cukup yakni 1 (satu) peraturan daerah, 1 (satu) Rencana strategis Diskominfo, 3 (tiga) Peraturan bupati dan 3 (tiga) surat edaran Kepala Diskominfo. Supratruktur tersebut yaitu:

1. Perda Nomor 12 Tahun 2016 tentang RPJMD Kab. Purworejo Tahun 2016 - 2021

2. Renstra Dinas Kominfo Tahun 2016 - 2021, berisi progam dan kegiatan Dinas Kominfo Kab. Purworejo

3. Perbup Nomor 24 Tahun 2017 tentang Pedoman Pengelolaan Pelayanan Informasi dan Dokumentasi di Lingkungan Pemerintah $\mathrm{Kb}$. Purworejo

4. Perbup Nomor 46 Tahun 2017 tentang Penyelenggaraan dan Pelayanan Publik di Lingkungan Pemerintah Kab. Purworejo

5. Perbup Nomor 52 Tahun 2017 tentang Penyelenggaraan Kepemerintahaan Berbasis Elektronik (e-Government) di Lingkungan Pemerintah Kab. Purworejo

6. SE Kepala Dinas Kominfo Nomor 543/426.1/2018 Surat Edaran tentang Pelaksanaan Perbup Nomor 52 Tahun 2017 tentang Pelaksanaan dan Pengembangan Penyelenggaraan Kepemerintahaan Berbasis Elektronik di Lingkungan Pemerintahan Kab. Purworejo

7. SE Sekda Nomor 011.4/14.109/2018, Surat Edaran Pemanfaatan Teknologi Informasi dalam Penyelenggaraan Pemerintahan dan Pelayanan Publik di Lingkungan Pemerintah Kab. Purworejo

8. SE Sekda Nomor 011.4/758/2019 Surat Edaran tentang Pedoman Teknis Pemanfaatan Teknologi Informasi dalam Penyelenggaraan Pemerintahan dan Pelayanan Publik di Lingkungan Pemerintah Kab. Purworejo

Dalam mendukung Kab. Purworejo menuju smart city kesiapan infrastruktur sangat diperlukan untuk mendukung 6 (enam) komponen smart tersebut. Infrastruktur yang telah dimiliki Kab. Purworejo ditunjukkan pada Tabel 4.

Tabel 4. Kesiapan Infrastruktur

\begin{tabular}{|c|l|l|}
\hline No & \multicolumn{1}{|c|}{ Ketersediaan } & Kondisi \\
\hline 1 & Jaringan 3G / 4G & Ada \\
\hline 2 & Broadband akses & Ada \\
\hline 3 & Akses internet & Ada \\
\hline 4 & Jaringan antar SKPD & Ada \\
\hline 5 & $\begin{array}{l}\text { Hotspot pemerintah dan } \\
\text { publik }\end{array}$ & Ada \\
\hline 6 & Data center pemerintah & Belum \\
\hline 7 & Data center recovery & Belum \\
\hline 8 & Lab. komputer & Ada \\
\hline 9 & VOIP & Ada \\
\hline
\end{tabular}

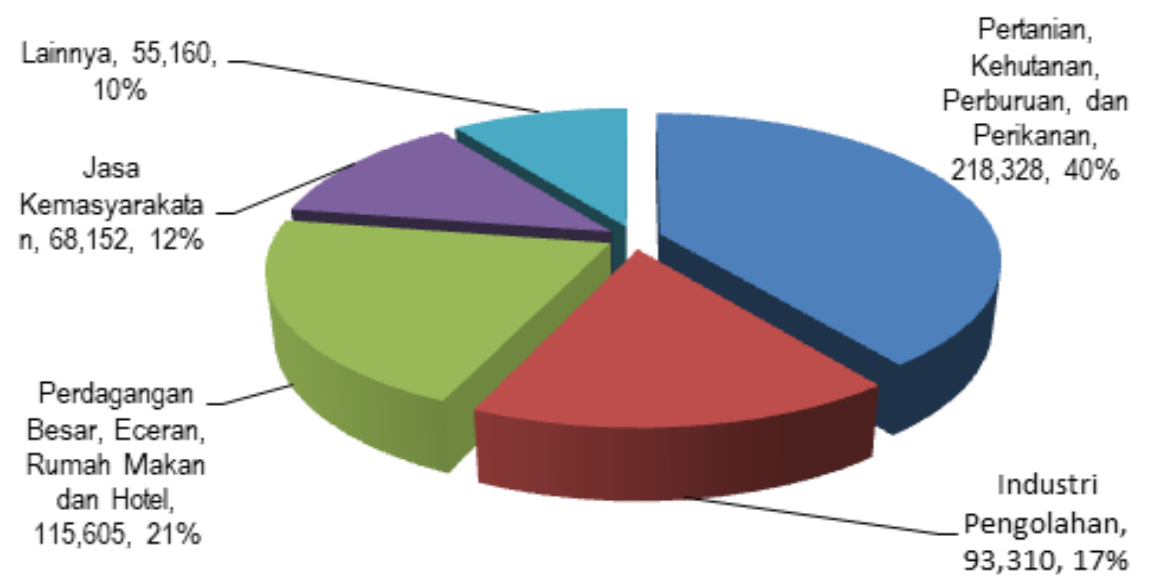

Gambar 6. Data Grafik Berbagai Sektor Tahun 2018 (Forum Komunikasi, April 2019) 


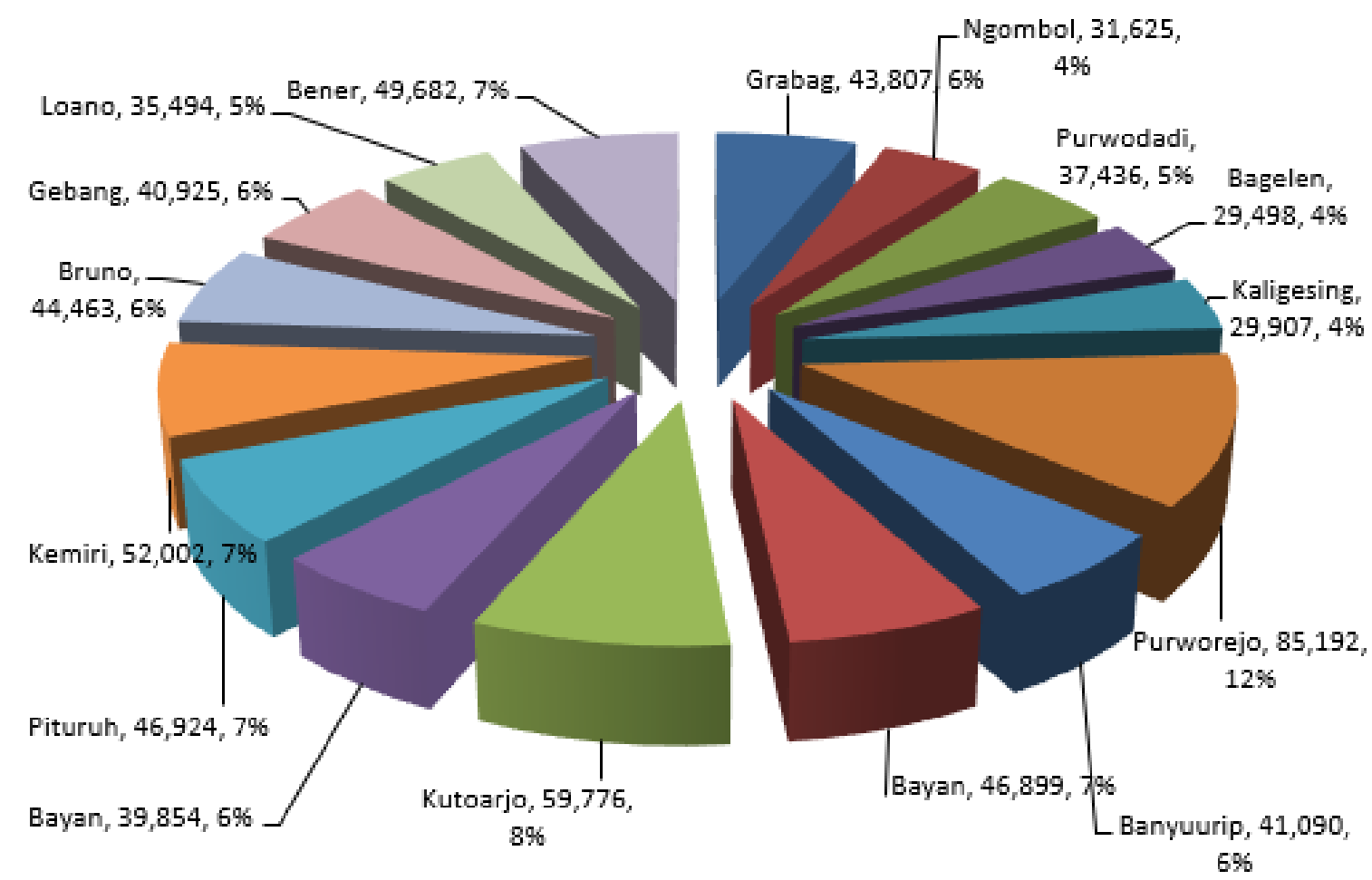

Gambar 7. Sumber Daya Manusia Potensial Yang Tersebar Semua Kecamatan di Kab. Purworejo

(Forum komunikasi, April 2019)

Jaringan fiber optik juga telah merambah 16 kecamatan artinya telah $100 \%$ terpenuhi. Pemasangan kabel fiber optik ini untuk mendukung infrastruktur sektor TIK supaya masayarakat merasakan kemudahan akses terhadap informasi yang diperlukan. Peta jaringan fiber optik ditunjukkan pada Gambar 7. Pemasangan kabel fiber optik Diskominfo bekerjasama dengan salah satu provider telekomunikasi BUMN.

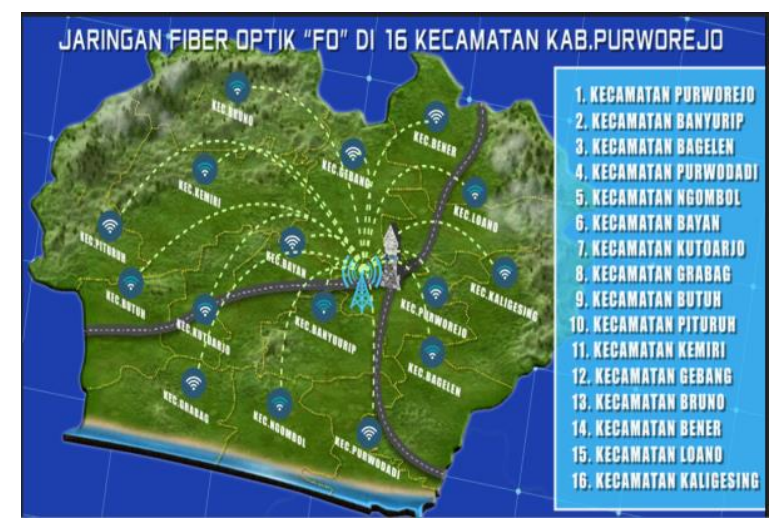

Gambar 7. Jaringan Fiber Optik di 16 Kecamatan Kab. Purworejo ((Forum komunikasi, April 2019)

Kapasitas bandwith telah ditingkatkan menjadi 400Mbps dengan backup bandwith $150 \mathrm{Mpbs}$ penggunaan tersebar di 42 OPD dan 40 titik hotspot untuk area publik. Dengan infrastruktur yang seperti ini dirasa sudah cukup untuk membangun smart city secara minor. Selanjutnya lingkup mayor dilakukan bertahap menyesuaikan APBD Kab. Purworejo. Aplikasi, website atau sistem informasi yang telah dibangun oleh Kab. Purworejo dalam mendukung smart city terdapat 13 bidang yang belum tersentuh TIK dari 40 bidang.

\section{KESIMPULAN}

Penelitian ini menyimpulkan bahwa Kab. Purworejo telah siap menuju smart city skala minor, secara bertahap dapat ditingkat kearea yang lebih luas. Hal ini ditunjukkan tersedia jaringan fiber optik yang mencakup 16 kecamatan. 7 (tujuh) dari 9 (sembilan) infrastruktur TIK telah dibangun. Masyarakat usia produktif Kab. Purworejo cukup untuk mendukung smart city. Dari data grafik, sektor pertanian, kehutanan, keburuan, perikanan menunjukkan prosentasi paling tinggi. Sehingga Kab. Purworejo dapat fokus pada smart economy dan smart mobility. 40 bidang di Kab. Purworejo terdapat 13 bidang belum memanfaatkan teknologi informasi. Namun secara umum Kab. Purworejo siap menuju smart city secara minor. 


\section{DAFTAR PUSTAKA}

Ayoub A., Bassma Z., Essaid S., Mohamed S., (2016). A Literature Review on Smart Cities: Paradigms, Opportunities and Open Problems. IEEE Confrence. http://dx.doi.org/10.1109/WINCOM.2016. 7777211

Supangat S.H., (2015). Pengenalan dan Pengembangan Smart City. Bandung: e-Indonesia Initiatives.

Kota Jogja Menuju Smart City Terdepan di Asia. (2018, 7 Oktober). Jawa Pos

Devega E. (2017, 28 November). Langkah Menuju "100 Smart City". https://kominfo.go.id/content/detail/11656/langkahmenuju-100-smart-city/0/sorotan_media. Diakses pada tanggal 02 Maret 2019.

Giffinger, R., Fertner, C., Kramar, H., Meijers, E. (2007). Smart cities: Ranking of European medium-sized cities. University of Technology, Vienna Austria.

Torres L., Pina V., Sonia R, (2005). E-government and the transformation of public administrations in EU countries: Beyond NPM or just a second wave of reforms?, Online Information Review 29(5): 531553,

Hollands, R. G. Will the real smart city please stand up?, City 12(3): 303320, 2008, http://dx.doi.org/10.1080/1360481080247 9126

Ariffin, A. Iskandar. (2012). Malaysias Definition of Smart City., diakses tanggal 6 Januari 2019. Tersedia di internet: http://sustainableiskandar.com.my/iskandarmalaysiasdefinition-of-smart-city/

Davies, A. R. \& Mullin, S. J. (2011). Greening The Economy: Interrogating Sustainability Innovations Beyond The Mainstream, Journal of Economic Geography 11: 7938162008 , http://dx.doi.org/10.1093/jeg/lbq050

Campbell, T. (2009). Learning cities: Knowledge, capacity and competitiveness, Habitat
International, 33(2). http://dx.doi.org/ 195201

H. Chourabi, T. Nam, S. Walker, J.R. Gil-Garca, S. Mellouli, K. Nahon, T.A. Pardo, H.J. Scholl. (2012). Understanding smart cities: an integrative framework, Proceeding of HICSS. pp. 22892297

Scholl, H. J., Barzilai-Nahon, K., Ahn, J-H., Olga, P. \& Barbara, R. (2009). E-commerce and e-government: How do they compare? What can they learn from each other?, Proceedings of the 42nd Hawaiian International Conference on System Sciences

Clay G. Nesler, Kirk H. Drees, James P. Kummer, Derek Supple, Marc D. Andraca, John I. Ruiz, Paul Harrison Rode, Moins. (2010). Smart building manager. US 8600556 B2 Diakses dari alamat: http://www.neraca.co.id/article/93533/langkah-menuju-100-smart-city tanggal 3 Maret 2019

Badan Pusat Statistik. (2017). Purworejo Dalam Angka 2017. Kab. Purworejo: Badan Pusat Statistik Purworejo.

Santosa B. \& Umam A. (2018). Data Mining dan Big Data Analytics, Teori dan Implementasi Menggunakan Python dan Apache Spark. Penebar Media Pustaka. Cetakan 1.

Sandhi H.F, Supangat S.H., Arman A.A., Ariani Y. (2017). Identifying Component for Building Smart City Maturity Model Through Document Based Weighting and City Problem in Indonesia. IEEE Confrence. $2155-6830$

Sri Palupi, 2019, Pemaparan Materi Smart City, Forum Komunikasi dan OPD, Diskominfo, Kab. Purworejo 